\title{
Productivity, Quality and Economics of High Density Planted Cotton as Influenced by Varieties and Fertilizer Application
}

\author{
R. Veeraputhiran* and K. Thiyagu \\ Cotton Research Station (TNAU), Srivilliputtur, Tamil Nadu, India \\ *Corresponding author
}

\section{A B S T R A C T}

\section{Keywords}

High Density Planted Cotton,

Fertilizer

Application

Article Info

Accepted:

22 April 2021

Available Online:

10 May 2021
Field experiments were carried out at Cotton Research Station, Tamil Nadu Agricultural University, Srivilliputtur, during winter irrigated season 2018-19 and 2019-20 (August to February) to find out suitable varieties and to standardize optimum fertilizer requirement of cotton under HDPS. The experiments were conducted in split plot design with three replications. The treatments consisted of three compact varieties / cultures viz., TCH 1705 (CO 15), TCH 1819 (CO 17) and TCH 1822 in main plots and four doses of fertilzers (100 \% RDF - 80:40:40 Kg NPK / ha, 125\% RDF- 100:50:50 Kg NPK /ha, $150 \%$ RDF- 120 :60: $60 \mathrm{Kg} \mathrm{NPK} /$ ha and STCR based fertilizer application - 55 :20: $20 \mathrm{Kg} \mathrm{NPK} / \mathrm{ha}$ ) in sub plots. The results revealed that the pre release culture TCH 1822 registered the highest seed cotton yield of 2458 and $2427 \mathrm{~kg} / \mathrm{ha}$ during 2018-19 and 2019-20 respectively which were comparable with CO 17 (2421 and $2402 \mathrm{~kg} / \mathrm{ha}$ ) and both these varieties were significantly higher than CO 15 (2290 and $2235 \mathrm{~kg} / \mathrm{ha}$ ).Though the application of $150 \%$ RDF produced the highest seed cotton yield of 2604 and $2563 \mathrm{~kg} / \mathrm{ha}$, it was on par with $125 \%$ RDF (2447 and $2426 \mathrm{~kg} / \mathrm{ha}$ ). The STCR based nutrient application recorded comparable seed cotton yield (2216 and $2201 \mathrm{~kg} / \mathrm{ha}$ ) with $100 \% \mathrm{RDF}$. The varieties TCH 1822 and CO 17 registered better quality parameters. Higher economic benefits like total income, net income and benefit cost ratio were also associated with the varieties TCH 1822 and CO 17 and $125 \%$ RDF. It can be concluded from the study that the varieties TCH 1822 and CO 17 were highly suitable for HDPS with a fertilizer dose of 100:50:50 Kg NPK / ha for higher seed cotton yield with better economic returns and higher quality paramaters which will pave way for sustainable cotton production. The STCR based nutrient application was sufficient to obtain comparable yield and economics with $100 \%$ RDF.

\section{Introduction}

Cotton, popularly known as "King of fibre" and "White gold" is the most important fibre and commercial crop of India and Tamil Nadu state as well. The contribution of India to global cotton fibre and edible oil production is
44 and 10 per cent respectively. Though India has the largest area (26 per cent) of cotton in the world, due to its lower productivity the share to the total world cotton production is only 12 per cent. In order to meet the demandand to satisfy the native mill requirement of cotton, the productivity of 
cotton should be increased. High Density Planting System (HDPS) is recently considered as an alternate production system having a potential for improving the productivity and profitability, increasing input use efficiency, reducing input costs and minimizing the risks associated with the current production system in India (Venugopalan et al, 2013).

The concept on high density cotton planting is popular in several countries like Brazil, China, Australia, Spain, Uzbekistan, Argentina, USA and Greece with the availability of compact genotypes (Rossi et al., 2004). In India also this new method of planting system studies were initiated and yield benefits were observed (CICR, 2013). Development of ideal varieties having better adaptation to high density planting with better quality characters and optimum fertilizer dose is paramount importance for this new method of HDPS. With this back ground, present investigation was carried out evaluate suitable varieties and to standardize optimum fertilizer requirement of cotton under HDPS.

\section{Materials and Methods}

Field experiments were carried out at Cotton Research Station, Tamil Nadu Agricultural University, Srivilliputtur, during winter irrigated season 2018-19 and 2019-20 (August to February) to find out suitable varieties and to standardize optimum fertilizer requirement of cotton under HDPS. The experiments were conducted in split plot design with three replications.

The treatments consisted of three compact cultures viz., TCH 1705 (CO 15), TCH 1819 (CO 17) and TCH 1822 in main plots and four doses of fertilzers (100\% RDF - 80:40:40 Kg NPK / ha, 125\% RDF- 100:50 :50 Kg NPK /ha, $150 \%$ RDF- 120 :60: $60 \mathrm{Kg}$ NPK/ ha and STCR based fertilizer application - $55: 20: 20$
Kg NPK/ ha) in sub plots. High density planting system was followed with a spacing of $100 \times 10 \mathrm{~cm}$ and weeding was carried out by power weeder three times i.e20, 40 and 60 Days After Sowing (DAS) . The soil of the experimental field was sandy clay loam and available soil nutrient status was low in $\mathrm{N}$ (196 kg/ ha), high in $\mathrm{P}(40 \mathrm{Kg} / \mathrm{ha})$ and $\mathrm{K}$ (496 kg/ha). The 50 per cent of $\mathrm{N}$ and $\mathrm{K}$ and 100 per cent of $\mathrm{P}$ as basal and the remaining 50 per cent of $\mathrm{N}$ was applied in two equal splits on 20 and 40 DAS and the remaining of $\mathrm{K}$ was on 40 DAS. The seed cotton yield was recorded and quality parameters were analysed as per standard procedures. Economics were also worked out.

\section{Results and Discussion}

\section{Seed cotton yield}

Both varieties and nutrient levels exerted significant influence on seed cotton yield (Table 1). Among the varieties, TCH 1822 (2458 and $2427 \mathrm{~kg} / \mathrm{ha}$ ) and CO 17 (2421 and $2402 \mathrm{~kg} / \mathrm{ha}$ ) registered comparable and significantly higher seed cotton yield than $\mathrm{CO}$ 15 (2290 and $2235 \mathrm{~kg} / \mathrm{ha})$. The variation in seed cotton yield was due to the specific varietal characteristics of higher boll weight associated with TCH 1822 and CO 17. Similar results of higher seed cotton yield with the varieties CO 17 and TCH 1822 were observed by Kanchana et al., (2019) at Coimbatore conditions.

Application of $150 \%$ RDF produced the highest seed cotton yield of 2504 and 2463 $\mathrm{kg} / \mathrm{ha}$ which were on par with $125 \% \mathrm{RDF}$ (2447 and $2426 \mathrm{~kg} / \mathrm{ha})$ and significantly higher than other two nutrient levels. The STCR based nutrient application recorded comparable seed cotton yield (2216 and 2201 $\mathrm{kg} / \mathrm{ha}$ ) which were on par with that of $100 \%$ RDF. 
Table.1 Effect of varieties and fertilizer levels on yield and economics of high density planted cotton

\begin{tabular}{|c|c|c|c|c|c|c|c|c|c|c|}
\hline \multirow[t]{2}{*}{ Treatment } & \multicolumn{2}{|c|}{ Seed cotton yield $(\mathrm{kg} / \mathrm{ha})$} & \multicolumn{2}{|c|}{$\begin{array}{l}\text { Cost of cultivation } \\
\text { (Rs/ha) }\end{array}$} & \multicolumn{2}{|c|}{$\begin{array}{l}\text { (Gross Income } \\
\quad(\mathrm{Rs} / \mathrm{ha})\end{array}$} & \multicolumn{2}{|c|}{$\begin{array}{l}\text { Net Income } \\
\text { (Rs/ ha) }\end{array}$} & \multicolumn{2}{|c|}{$\begin{array}{c}\text { Benefit } \\
\text { Cost Ratio }\end{array}$} \\
\hline & 2018-19 & 2019-20 & 2018-19 & 2019-20 & 2018-19 & 2019-20 & 2018-19 & 2019-20 & 2018-19 & 2019-20 \\
\hline \multicolumn{11}{|l|}{ Variety / genotype } \\
\hline $\mathrm{M}_{1}-$ TCH 1705 (CO 15) & 2290 & 2235 & 53200 & 54800 & 105340 & 82695 & 52140 & 27895 & 1.98 & 1.51 \\
\hline $\mathrm{M}_{2-}$ ТCH 1819 (CO 17) & 2421 & 2402 & 53200 & 54800 & 111366 & 88874 & 58166 & 34074 & 2.09 & 1.62 \\
\hline $\mathrm{M}_{3}-\mathrm{TCH} 1822$ & 2458 & 2427 & 53200 & 54800 & 113068 & 89799 & 59868 & 34999 & 2.13 & 1.64 \\
\hline SEd. & 62.7 & 69.1 & - & - & - & - & - & - & - & - \\
\hline $\mathrm{CD}(\mathrm{P}=0.05)$ & 147.1 & 161.7 & - & - & - & - & - & - & - & - \\
\hline \multicolumn{11}{|l|}{ Nutrient levels } \\
\hline $\begin{array}{l}S_{1} \cdot-100 \% \text { RDF } \\
(80: 40: 40 \mathrm{Kg} \text { NPK /ha) }\end{array}$ & 2241 & 2265 & 53200 & 54800 & 103086 & 83805 & 49886 & 29005 & 1.94 & 1.53 \\
\hline $\begin{array}{l}S_{2}-125 \% \text { RD F } \\
(100: 50: 50 \text { Kg NPK/ ha })\end{array}$ & 2447 & 2426 & 55900 & 57500 & 112562 & 89762 & 56662 & 32262 & 2.01 & 1.56 \\
\hline $\begin{array}{l}S_{3}-150 \% \text { RD F } \\
(120: 60: 60 \mathrm{Kg} \text { NPK/ ha })\end{array}$ & 2604 & 2563 & 57600 & 59200 & 115184 & 91131 & 57584 & 31930 & 2.00 & 1.53 \\
\hline $\begin{array}{l}S_{4}-\text { STCR based } \\
(55: 20: 20 \mathrm{Kg} \mathrm{NPK/ha)}\end{array}$ & 2216 & 2201 & 51100 & 52700 & 101936 & 81437 & 49236 & 28737 & 1.99 & 1.55 \\
\hline SEd. & 94.3 & 100.5 & - & - & - & - & - & - & - & - \\
\hline $\mathrm{CD}(\mathrm{P}=\mathbf{0 . 0 5})$ & 198.6 & 211.5 & - & - & - & - & - & - & - & - \\
\hline Interaction & NS & NS & - & - & - & - & - & - & - & - \\
\hline
\end{tabular}


Table.2 Effect of varieties and fertilizer levels quality parameters of high density planted cotton

\begin{tabular}{|c|c|c|c|c|c|c|c|c|c|c|}
\hline \multirow[b]{2}{*}{ Treatment } & \multicolumn{2}{|c|}{ UHML } & \multicolumn{2}{|c|}{ Fibre strength } & \multicolumn{2}{|c|}{ Mic } & \multicolumn{2}{|c|}{ Uniformity ratio } & \multicolumn{2}{|c|}{ Elongation ratio } \\
\hline & 2018-19 & 2019-20 & 2018-19 & 2019-20 & 2018-19 & 2019-20 & 2018-19 & 2019-20 & 2018-19 & 2019-20 \\
\hline \multicolumn{11}{|l|}{ Variety / genotype } \\
\hline $\mathrm{M}_{1}-\mathrm{TCH} 1705$ (CO 15) & 25.20 & 25.50 & 27.83 & 27.40 & 4.50 & 4.81 & 83.50 & 83.03 & 5.53 & 5.55 \\
\hline $\mathrm{M}_{2-}$ TCH 1819 (CO 17) & 27.53 & 27.38 & 30.08 & 29.95 & 4.22 & 4.50 & 84.48 & 83.13 & 5.68 & 5.70 \\
\hline $\mathrm{M}_{3}-\mathrm{TCH} 1822$ & 25.43 & 27.35 & 30.50 & 29.23 & 4.15 & 4.49 & 84.20 & 83.48 & 5.73 & 5.68 \\
\hline SEd. & 0.81 & 0.69 & 0.85 & 0.72 & 0.92 & 0.99 & - & - & - & - \\
\hline $\mathrm{CD}(\mathrm{P}=0.05)$ & 2.01 & 1.73 & 2.14 & 1.80 & 0.23 & 0.25 & NS & NS & NS & NS \\
\hline \multicolumn{11}{|l|}{ Nutrient levels } \\
\hline $\begin{array}{l}S_{1} \cdot \quad-100 \% \text { RDF } \\
(80: 40: 40 \mathrm{Kg} \mathrm{NPK} / \mathrm{ha})\end{array}$ & 26.10 & 27.50 & 29.20 & 28.13 & 4.54 & 4.56 & 84.00 & 83.33 & 5.63 & 5.70 \\
\hline $\begin{array}{l}S_{2}-125 \% \text { RD F } \\
(100: 50: 50 \text { Kg NPK/ ha })\end{array}$ & 25.63 & 27.70 & 29.57 & 28.17 & 4.33 & 4.67 & 84.27 & 83.33 & 5.63 & 5.63 \\
\hline $\begin{array}{l}S_{3}-150 \% \text { RD F } \\
(120: 60: 60 \mathrm{Kg} \text { NPK/ ha })\end{array}$ & 26.13 & 26.57 & 29.63 & 27.57 & 4.40 & 4.64 & 84.17 & 83.03 & 5.70 & 5.60 \\
\hline $\begin{array}{l}\text { S }_{4}-\text { STCR based } \\
(55: 20: 20 \mathrm{Kg} \mathrm{NPK/} \mathrm{ha)}\end{array}$ & 25.83 & 26.80 & 29.47 & 27.57 & 4.02 & 4.64 & 83.80 & 83.13 & 5.60 & 5.63 \\
\hline $\mathrm{CD}(\mathrm{P}=0.05)$ & NS & NS & NS & NS & NS & NS & NS & NS & NS & NS \\
\hline Interaction & NS & NS & NS & NS & NS & NS & NS & NS & NS & NS \\
\hline
\end{tabular}


Similar findings of higher yield with the application of $125 \%$ RDF for compact cultures were noticed by Kanchana et al., (2019). Rinehardt et al., (2003) also observed that about 30 per cent more $\mathrm{N}$ was required for high density planted cotton compared to the conventional method of cultivation.

\section{Quality parameters}

The effect of varieties and nutrient management on quality characters of cotton is presented in the Table 2 . The results showed that the uniformity and elongation ratio were similar for all the varieties during both the years of study. But significant variation was observed for other quality parameters by the varieties. All the varieties taken in the study were coming under the category of long staple length. However, among these varieties $\mathrm{CO}$ 17 and TCH 1822 were found to have significantly higher staple length, fibre length and also uniformity. The quality attributes of cotton are inherent and decided by the individual characteristics of the particular variety or genotype and hence variation was noticed in the present investigation. Similar significant difference among cotton varieties on quality parameters was reported by PradapKumar et al., (2017). During both the years of study, the quality parameters did not differ significantly due to various level of nutrient application. Similar non significant effect on quality of cotton by the levels of fertilizers as reported by Ganvir et al., (2014) and Bharathi et al., (2016) were in accordance with the present study.

\section{Economics}

The economic analysis (Table 2) revealed that the variety TCH 1822 recorded the highest net income of Rs59868 ha ${ }^{-1}$ and Rs $34999 \mathrm{ha}^{-1}$ and $\mathrm{B}-\mathrm{C}$ ratio of 2.13 and 1.64 followed by CO 17 which recorded net income of Rs $58166 \mathrm{ha}^{-1}$ and Rs $34074 \mathrm{ha}^{-1}$ and B - C ratio of 2.09 and 1.62 respectively during the first and second year of experimentation and both these were substantially higher than that $\mathrm{CO}$ 15. The higher economic benefits of these two varieties were due to the reflection of higher seed cotton yield.

Regarding nutrient application, application highest dose of nutrients at $125 \% \mathrm{RDF}$ recorded higher gross income, net income and also benefit cost ratio which was closely followed by that of $150 \%$ RDF. In addition it is also observed that STCR based nutrient application registered comparable net income and higher B-C ratio than $100 \%$ RDF. Jagvir Singh et al., (2012) and Ganvir et al., (2014) also found that higher economic benefits with $125 \%$ and $150 \%$ RDF respectively under high density planted cotton. Veeraputhiran and Gunasekaran (2018) observed higher economic benefits with higher doses of fertilizer levels in cotton hybrids also in conformity with the present investigation.

It can be concluded from the study that the varieties TCH 1822 and CO 17 were highly suitable for HDPS with a fertilizer dose of 100:50:50 Kg NPK / ha for higher seed cotton yield and economic benefits with better quality which will pave way for sustainable cotton production. The STCR based nutrient application was sufficient to obtain comparable yield and economics with $100 \%$ RDF.

\section{References}

Bharathi, S., RatnaKumari, S., Vamsi Krishna, A. N. and Chenga Reddy. 2016. Effect of nitrogen levels, split application of nitrogen on yield and fibre quality of Bt cotton in vertisols. $J$. Cotton Res. Dev.30 (2):201-2

CICR News Letter, 2013. High density cotton planting for improving rainfed cotton productivity in vidarbha.28 (2) :17-19 
Ganvir, S.S. Mangala Ghanbahadur and Khargkharate.,V.K. 2014. Effect of high density planting, nutrient management and land configuration on economics and nutrient uptake ofhirsutum cotton. Green Farming. 5 (1) : 92-94

Jagvir Singh, Shilpa Babar, Shalu Abraham,. Venugopalan, M.V. and Majumdar.,G. 2012. Fertilization of high density, rainfed cotton grown on vertisols of India. Better crops. 96 (2) : 26- 28.

KanchanaT., Sakthivel, N.,Thavaprakaash, N. and Balamurugan,J.2019. Performance of compact cotton (Gossypium hirsutum L.) genotypes to varied nutrient levels under high density planting system in winter irrigated condition. $J$. Pharmacognosy and Phytochemistry. 8(3): 3084-3088

Pradap Kumar, Karle, A.S., Deshraj Singh1 and LalitaVerma2017.Effect of High Density Planting System (HDPS) and Varieties on Yield, Economics and Quality of Desi Cotton. Int.J.Curr.Microbiol.App.Sci.6(3): 233238
Rinehardt, J.M.Edmisten. K..L., Wells. R., and Faircloth,J.C..2003. Response of ultra narrow and conventional spaced cotton to variable nitrogen rates.J. Plant Nutr. 27: 741- 753.

Rossi, J., Novick, G., Murray, J., Landivar, J., Zhang, S., Baxevanos, D., Mateos, A., Kerby, T., Hake,K.and Krieg,D. 2004. Ultra Narrow Row Cotton: Global perspective and reduce pesticide use. Proceedings of the Technical seminar of the $3^{\text {rd }}$ plenary Meeting of the ICAC : How to improve yields.Mumbai, India.November 2004 pp. 7-11

Veeraputhiran, R. and Gunasekaran, M. 2018. Optimization of fertilizer requirement for $\mathrm{Bt}$ and non $\mathrm{Bt}$ cotton hybrids under two geometry levels. J. Cotton Res.Dev.32 (2): 236-239

Venugopalan, M.V., Kranthi, K. R., Blaise., D., ShubhangiLakde and Sankaranarayanan, K.. 2013.High density planting systems in cotton - The Brazil Experience and Indian Initiative.Cotton Res. J. 5 (2): 172 -185

\section{How to cite this article:}

Veeraputhiran, R. and Thiyagu, K. 2021. Productivity, Quality and Economics of High Density Planted Cotton as Influenced by Varieties and Fertilizer Application. Int.J.Curr.Microbiol.App.Sci. 10(05): 581-586. doi: https://doi.org/10.20546/ijcmas.2021.1005.065 